\title{
Mouse Model of Poorly Differentiated Thyroid Carcinoma Driven by STRN-ALK Fusion
}

Alyaksandr V. Nikitski, * Susan L. Rominski, * Mamta Wankhede, ${ }^{\dagger}$ Lindsey M. Kelly, ${ }^{*}$ Federica Panebianco, * Guillermo Barila, Daniel L. Altschuler, ${ }^{\dagger}$ and Yuri E. Nikiforov*

From the Departments of Pathology* and Pharmacology and Chemical Biology, ${ }^{\dagger}$ University of Pittsburgh, Pittsburgh, Pennsylvania

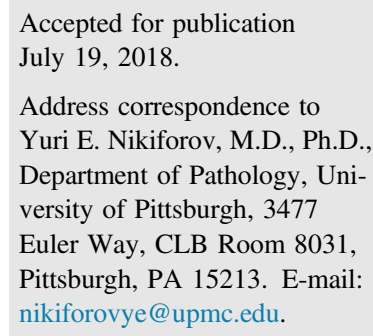

Address correspondence to Yuri E. Nikiforov, M.D., Ph.D., Department of Pathology, University of Pittsburgh, 3477 Euler Way, CLB Room 8031, Pittsburgh, PA 15213. E-mail: nikiforovye@upmc.edu.

\begin{abstract}
Chromosomal rearrangements of the $A L K$ gene, which lead to constitutive activation of ALK tyrosine kinase, are found in various cancers. In thyroid cancers, ALK fusions, most commonly the STRN-ALK fusion, are detected in papillary thyroid cancer and with higher frequency in poorly differentiated and anaplastic thyroid cancers. Our aim was to establish a mouse model of thyroid-specific expression of STRN-ALK and to test whether this fusion drives the development of thyroid cancer with a propensity for dedifferentiation. Transgenic Tg-STRN-ALK mice with thyroglobulin-controlled expression of STRN-ALK were generated and aged with or without goitrogen treatment. Thyroids from these mice were subjected to histologic and immunohistochemical analysis. Transgenic mice with thyroid-specific expression of STRN-ALK developed poorly differentiated thyroid tumors by the age of 12 months in $22 \%$ of mice without goitrogen treatment and in $36 \%$ of mice with goitrogen treatment. Histologically and immunohistochemically, the tumors resembled poorly differentiated thyroid cancers in humans, demonstrating a solid growth pattern with sheets of round or spindle-shaped cells, decreased expression of thyroglobulin, and a tendency to lose E-cadherin. In this study, we report a novel mouse model of poorly differentiated thyroid cancer driven by the STRN-ALK oncogene with phenotypic features closely recapitulating human tumor, and with a more pronounced phenotype after additional thyroidstimulating hormone stimulation. (Am J Pathol 2018, 188: 2653-2661; https://doi.org/10.1016/ j.ajpath.2018.07.012)
\end{abstract}

Cancer of the thyroid gland is the most common malignancy of the endocrine system, showing a steady increase in incidence since the 1980s. ${ }^{1-3}$ Among follicular cell-derived thyroid cancers, the most common papillary (PTC) and follicular thyroid carcinomas are typically indolent tumors, with a 5-year survival rate of $>95 \%$. ${ }^{4,5}$ In contrast, poorly differentiated (PDTC) and anaplastic (ATC) thyroid carcinomas are rare but highly aggressive tumors, with 5-year survival rates of approximately $50 \%$ and $<10 \%$, respectively. $^{4-6}$ High mortality from PDTC and ATC is associated with their widely invasive local growth, distant metastasis, and poor response to conventional therapies. These cancers are characterized by progressive loss of thyroid epithelial differentiation and, as a result, decreased or lost radioiodine avidity.

Poorly differentiated thyroid carcinoma accounts for $1 \%$ to $7 \%$ of thyroid malignancies in different geographic regions. $^{7-11}$ It has histopathological and molecular features intermediate between well-differentiated and anaplastic thyroid carcinomas. $^{12,13}$ Diagnostic criteria for PDTC include solid, insular, or trabecular patterns of growth; loss of the nuclear features of papillary thyroid carcinoma; and some high-grade features, including high mitotic activity and presence of necrosis. ${ }^{14}$ These tumors lose follicular organization and show a decrease or complete loss of thyroglobulin expression, whereas the expression of several other thyroid differentiation markers, including transcriptional factors TTF1, FOXE1, and PAX8, is typically preserved. $^{8,15-18}$ In addition to thyroid functional dedifferentiation, PDTC tumors frequently lose some features of epithelial differentiation, such as expression of E-cadherin. $^{19}$

Supported by NIH grant R01CA181150.

Disclosures: None declared. 
Genetically, many poorly differentiated carcinomas show co-occurrence of early driver mutations, such as those affecting the $B R A F$ or $R A S$ genes, and late mutations, such as genetic alterations of TERT or TP53. The latter mutations, as well as genetic alterations in some genes of the phosphatidylinositol 3-kinase (PI3K)/AKT/mammalian target of rapamycin pathway (mTOR), SWI/SNF proteins, and histone methyltransferases, are enriched in poorly differentiated tumors compared with well-differentiated ones, supporting the idea that thyroid cancer progression is a result of the successive accumulation of mutational events. ${ }^{17,20-26}$ Furthermore, most of the transgenic mouse models of thyroid cancer show the development of advanced dedifferentiated thyroid tumors when driver oncogene $\mathrm{Braf}^{\mathrm{V600E}}, \mathrm{Kras}^{G 12 D}$, or RET/ $P T C 1$ or inactivation of the tumor suppressor Pten is combined with Trp53 loss or PIK3CA $A^{H 1047 R}$ or Thrb ${ }^{P V / P V}$ mutations. ${ }^{27-31}$ However, some studies reported that expression of $B R A F^{V 600 E}$ or $N R A S^{G 61 K}$ is sufficient to develop thyroid tumors that undergo dedifferentiation. ${ }^{32-35}$
The $A L K$ gene encodes a transmembrane receptor tyrosine kinase with tissue-specific expression. Chromosomal rearrangements of this gene to various partners lead to constitutive activation of ALK tyrosine kinase and represent a carcinogenic mechanism found in various cancer types, ${ }^{36-40}$ including non-small-cell lung cancer, where it is exploited as an important therapeutic target. ${ }^{41}$ We have recently reported $A L K$ gene fusions, predominantly $S T R N$ $A L K$, in thyroid cancers with the frequency of $1.6 \%$ in PTC, $9 \%$ in PDTC, and $4 \%$ in ATC. ${ }^{42}$ Several other studies have similarly found $A L K$ rearrangements in approximately $1 \%$ of PTCs, and with higher (4\%) frequency in PDTCs. ${ }^{17,20,43}$ In some of the PDTCs, ALK fusion was the only oncogene found, with no late mutations detected, ${ }^{17}$ raising a possibility that this oncogene alone may be sufficient to initiate a genetic program leading to cancer dedifferentiation.

The goal of this study was to establish a mouse model of thyroid-specific expression of $S T R N-A L K$ and test whether the expression of this chimeric oncogene is tumorigenic and

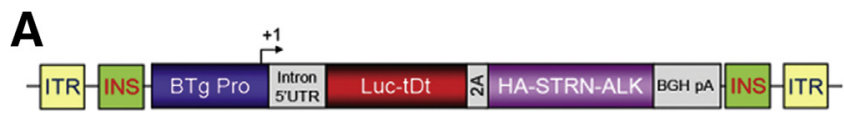

B

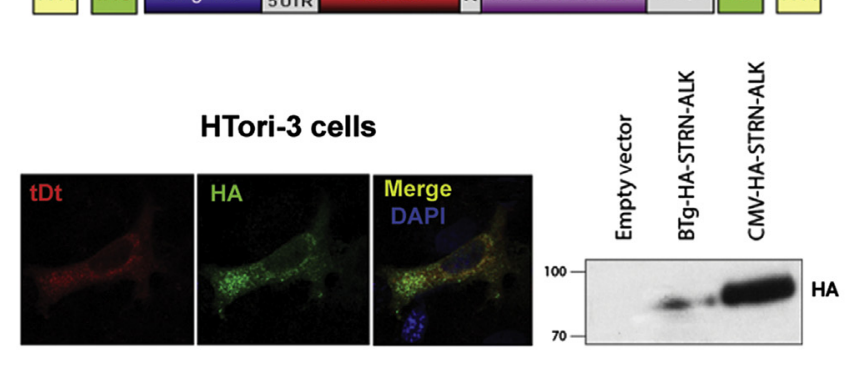

\section{Tg-STRN-ALK mice}

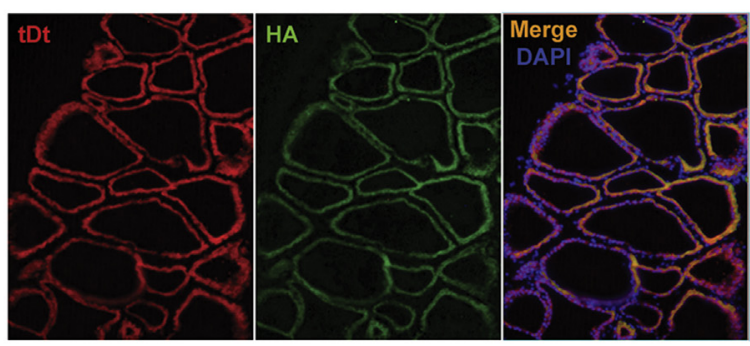

C

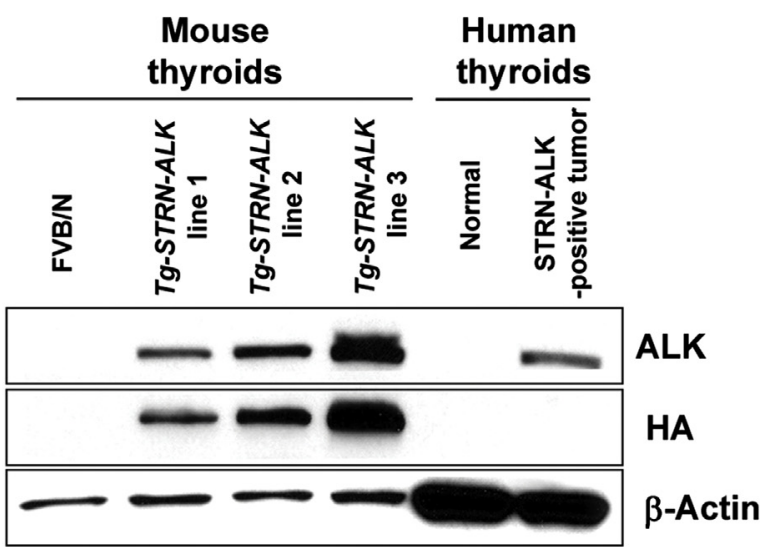

D

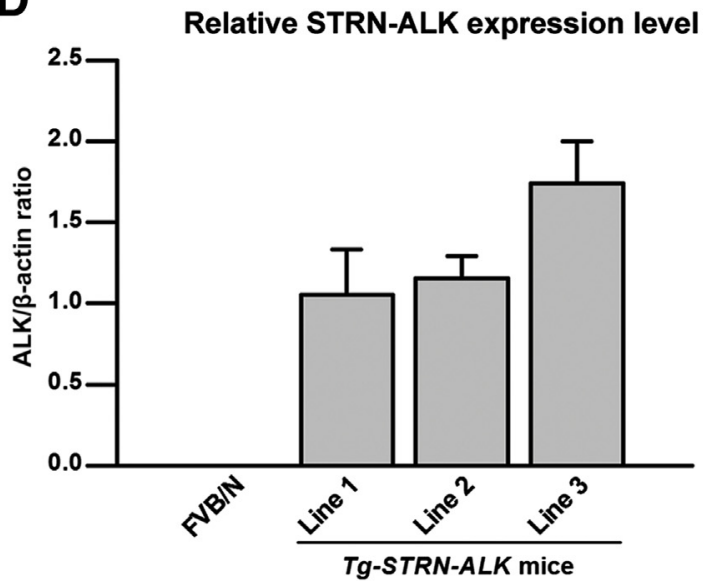

Figure 1 Generation of the transgenic mice with thyroid-specific expression of STRN-ALK fusion protein. A: Genetic construct containing sequences of the bovine thyroglobulin promoter (BTg Pro), reporter firefly luciferase-tandem dimmer Tomato (fLuc-tDt), and hemagglutinin (HA)-tagged STRN-ALK. Transcriptional activity of the promoter in thyroid cells was confirmed by detection of fLuc-tDt fluorescence and anti-HA immunoreactivity in immortalized normal thyroid HTori-3 cells transfected with initial plasmid containing the genetic construct. B: Immunofluorescence detection of the expression of the reporter tDt and anti-HA immunoreactivity in thyroid cells of founder Tg-STRN-ALK mouse. C and D: Western blot analysis and densitometry results showing expression of STRN-ALK in Tg-STRN-ALK mice thyroids (three to four thyroids per strain, age 6 months) and human STRN-ALK-positive papillary thyroid cancer sample. Original magnification: $\times 400(A) ; \times 200(B)$. UTR, untranslated region. 
sufficient to induce thyroid cancer with a propensity for dedifferentiation.

\section{Materials and Methods}

\section{Generation of Tg-STRN-ALK Mice and Experimental Design}

Sequences of the bovine thyroglobulin promoter fragment, reporter firefly luciferase-tandem dimmer Tomato, and human HA-tagged STRN-ALK fusion were used to generate a genetic construct (Figure 1A). Transcriptional activity of the promoter in thyrocytes was confirmed by detection of firefly luciferase-tandem dimmer Tomato fluorescence and anti-hemagglutinin (HA) immunoreactivity in normal thyroid HTori-3 cells transfected with an initial plasmid containing the above-mentioned construct. Transgenesis into $F V B / N$ mouse background was performed using pronuclear injection. Founder mice were screened for the presence of the transgene by PCR, as described below. Three independent strains were established, and STRN-ALK expression was validated by Western blot, immunofluorescence, and immunohistochemical analyses. Tg-STRN-ALK mice developed normally and showed mendelian inheritance of the transgene. Mice were bred and aged in a specific pathogen-free facility. Animal care and all experimental procedures were performed in accordance with the federal guidelines and institutional policies.

One strain (of three) of transgenic mice with a higher level of STRN-ALK expression was chosen for the detailed analysis. Wild-type $F V B / \mathrm{N}$ and $T g-S T R N-A L K$ mice were aged in standard conditions or treated with goitrogen. As goitrogen treatment, mice received $0.5 \mathrm{~g} / \mathrm{L}$ methimazole (M8506; Sigma, St. Louis, MO) and $5 \mathrm{~g} / \mathrm{L}$ sodium perchlorate (410241; Sigma) in drinking water starting from 5 weeks of age.

\section{Thyroid and Blood Serum Collection}

Animals were euthanized using $\mathrm{CO}_{2}$ with subsequent cervical dislocation. Serum was collected, and serum-free thyroxine was measured using a standard clinical immunoassay. Thyroids were snap frozen in liquid nitrogen and stored at $-80^{\circ} \mathrm{C}$ until use or fixed with $10 \%$ neutralbuffered formalin. After 24 hours' fixation in $10 \%$ neutralbuffered formalin at $4^{\circ} \mathrm{C}$, tissue samples were embedded into paraffin for sectioning. For cryosectioning, fresh tissue samples were fixed in $4 \%$ paraformaldehyde for 4 hours, equalized with $30 \%$ sucrose, and embedded in Tissue-Tek O.C.T. compound (Sakura Finetek, Torrance, CA) before sectioning.

\section{Western Blot Analysis}

Proteins were isolated from snap-frozen thyroids using RIPA buffer (Boston BioProducts, Ashland, MA) with protease inhibitors (Roche Diagnostics, Indianapolis, IN) and phosphatase inhibitors (Sigma). Protein concentration was determined using a BCA Protein Assay Kit (Thermo Fisher Scientific, Waltham, MA). Samples were resolved by SDS/PAGE (BioRad, Hercules, CA), transferred to the nitrocellulose membrane (BioRad), and immunoblotted with rabbit anti-ALK (1:2000; number 3633; Cell Signaling, Danvers, MA), anti-HA-Tag (1:1000; number 3724; Cell Signaling), or anti- $\beta$-actin (1:1000; sc1616; Santa Cruz Biotechnology, Dallas, TX) antibodies. Goat anti-rabbit IgG $(\mathrm{H}+\mathrm{L})$-horseradish peroxidase conjugate (1:3000; number 170-6515; BioRad) was used for detection of the immunoreactivity with primary antibodies.

\section{PCR Genotyping}

DNA was extracted from tails using QuickExtract DNA Extraction Solution (QE09050; Epicentre, Charlotte, NC) at the age of 10 to 15 days. Genotyping was performed by PCR using the forward: $5^{\prime}$-CAGTCGTCGTGCTGGAACA- $3^{\prime}$ and reverse: 5'-ACTCTTTGATGACCTCCTCGC-3' primers, yielding a 285-bp PCR product specific for $T g-S T R N-A L K$ mice.

\section{Immunohistochemistry}

Formalin-fixed, paraffin-embedded sections were deparaffinized and subjected to antigen retrieval with sodium citrate buffer, $\mathrm{pH} 6.0$, at $95^{\circ} \mathrm{C}$ for 20 minutes. Blocking reagent (Dako, Agilent Technologies, Santa Clara, CA) was applied at room temperature for 1 hour. After blocking, sections were incubated with primary antibodies diluted in Antibody Diluent (Dako) solution overnight at $4^{\circ} \mathrm{C}$ : anti-HA-Tag (1:400; number 3724; Cell Signaling), anti-TTF1 (1:500; ab13706; Abcam, Cambridge, MA), anti-thyroglobulin (1:3000; A251; Dako), anti-E-cadherin (1:100; number 3195; Cell Signaling), or anti-Ki-67 (1:500; ab15580; Abcam). After washing with phosphate-buffered saline (PBS), horseradish peroxidase-conjugated secondary antibodies anti-rabbit (1:100; P0448; Dako) were applied for 1 hour at room temperature. Visualization was performed with DAB Peroxidase Substrate Kit (SK-4100; Vector Laboratories, Burlingame, CA). The Ki-67 labeling index was

Table 1 Frequency of Poorly Differentiated Thyroid Carcinomas Developed in Tg-STRN-ALK Mice

\begin{tabular}{lllll}
\hline \multirow{2}{*}{ Goitrogen } & Mouse strain & \multicolumn{4}{l}{ Age group, months } \\
\cline { 3 - 5 } No & WT & $0 / 8$ & 6 & 12 \\
\hline \multirow{2}{*}{ Yes } & Tg-STRN-ALK & $0 / 9$ & $0 / 8$ & $0 / 9$ \\
& WT & $0 / 5$ & $0 / 6$ & $0 / 17^{*}$ \\
& Tg-STRN-ALK & $0 / 7$ & $0 / 9$ & $5 / 14(36)^{*}$ \\
\hline
\end{tabular}

Data are given as $n$ /total (percentage) *WT versus Tg-STRN-ALK, $P=0.047$ ( $\chi^{2}$ test). WT, wild type. 

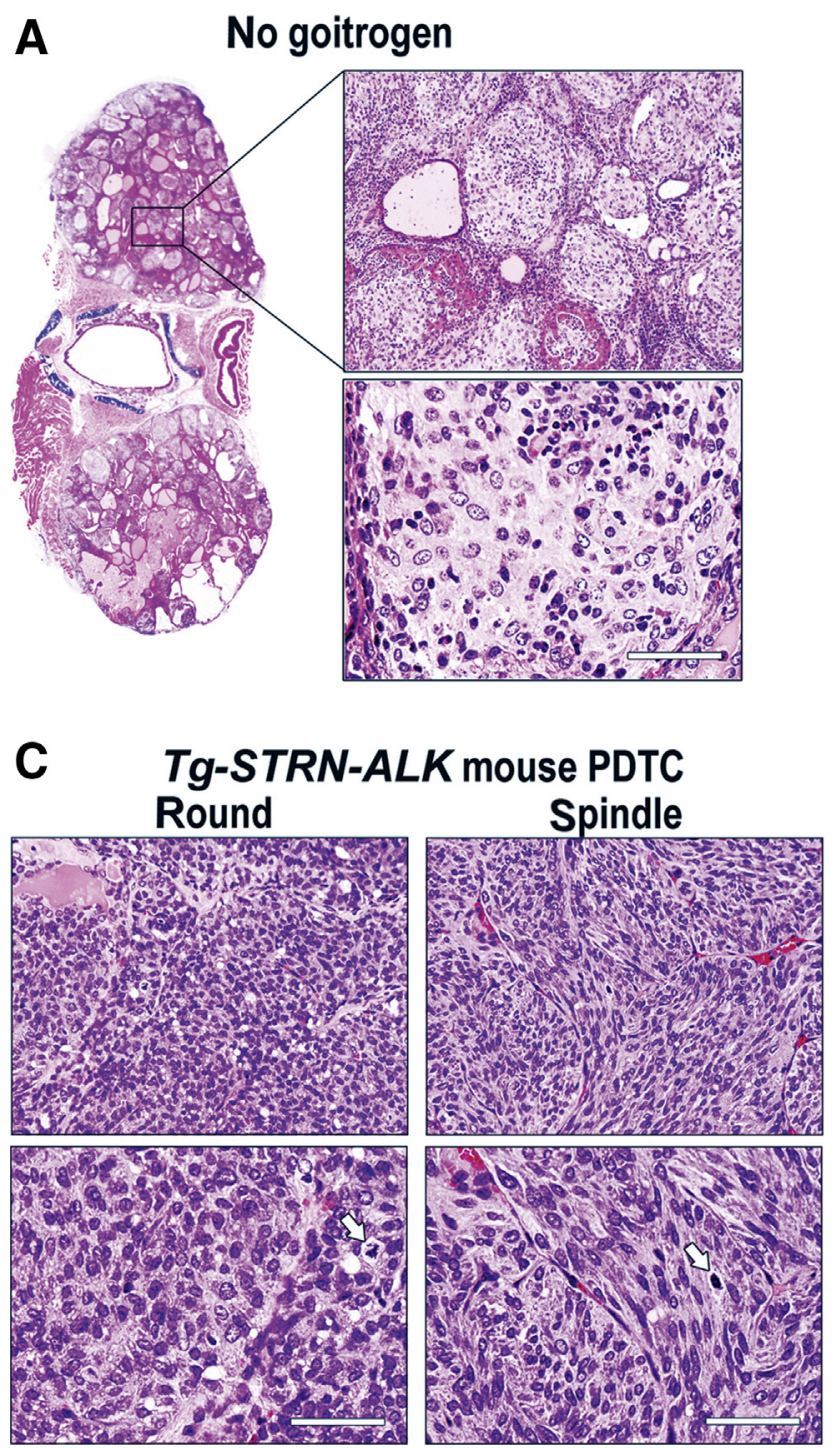

B Goitrogen

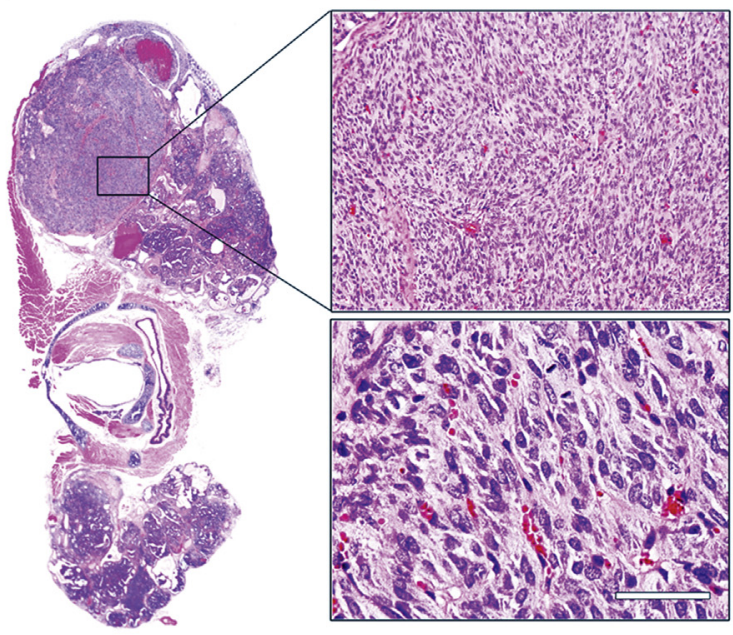

\section{Human STRN-ALK-positive PDTC Round}
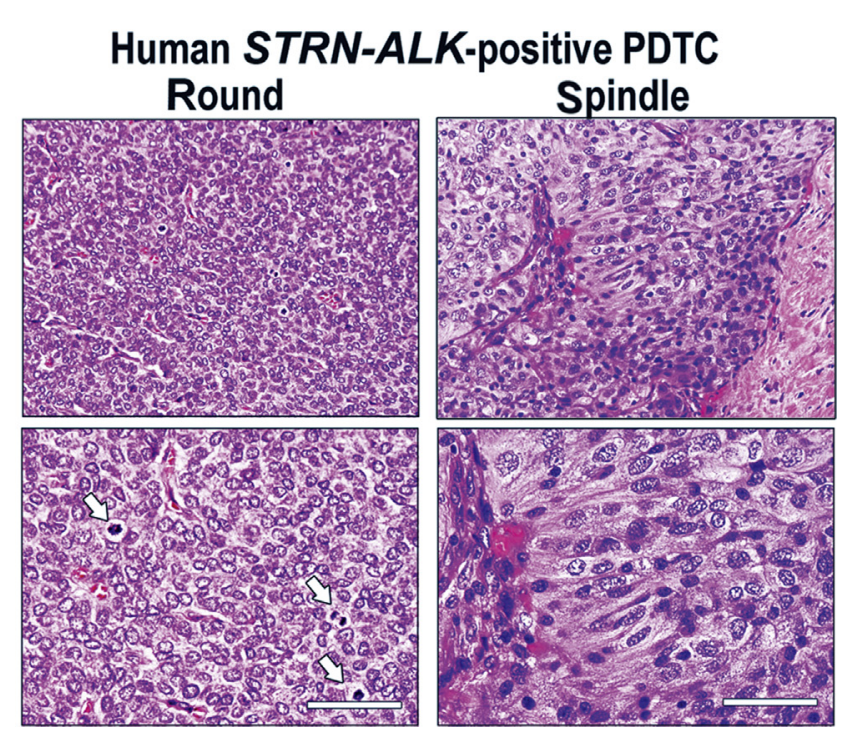

Figure 2 A and B: Histologic features of tumors in Tg-STRN-ALK mice without (A) and with (B) goitrogen treatment. C: Microscopic appearance of mouse and human STRN-ALK-positive poorly differentiated thyroid cancer showing tumor areas composed of confluent sheets of round-or spindle-shaped cells. Arrows show mitotic figures. Scale bar $=50 \mu \mathrm{m}(\mathbf{A}-\mathbf{C})$. Original magnifications: $\times 100$ (A and B, top panels); $\times 400($ A - C, bottom panels); $\times 200$ (C, top panels). PDTC, poorly differentiated thyroid carcinoma.

calculated as a percentage of positively stained nuclei of thyroid epithelial cells. At least 1000 thyroid epithelial cells were counted in random fields at $\times 400$.

\section{Immunofluorescence Analysis}

Cryosections were thawed out at room temperature and rehydrated in PBS. After incubation with blocking buffer (1\% fetal bovine serum in PBS) for 30 minutes at room temperature, primary rabbit antibody anti-HA-Tag (1:400; number 3724; Cell Signaling) diluted in incubation buffer (1\% bovine serum albumin, $0.5 \%$ fetal bovine serum, and $0.3 \%$ Triton X-100 in PBS) was applied for 30 minutes at $37^{\circ} \mathrm{C}$. After washing with PBS, anti-rabbit Alexa Fluor 488 (1:2000; Invitrogen, Carlsbad, CA) secondary antibody and DAPI (1:1000) diluted in incubation buffer were applied for 30 minutes at room temperature. Slides were mounted using antifade mounting media and analyzed using a fluorescent microscope.

\section{Statistical Analysis}

Statistical analysis was performed using $\chi^{2}$ test with IBM SPSS Statistics version 21 (IBM, Armonk, NY). $P$ values were two sided and considered significant if $<0.05$.

\section{Results}

Mice with Thyroid-Specific Expression of STRN-ALK Develop Thyroid Tumors by the Age of 12 Months

For the thyroid-specific expression of $S T R N-A L K$, a genetic construct containing bovine thyroglobulin promoter, 

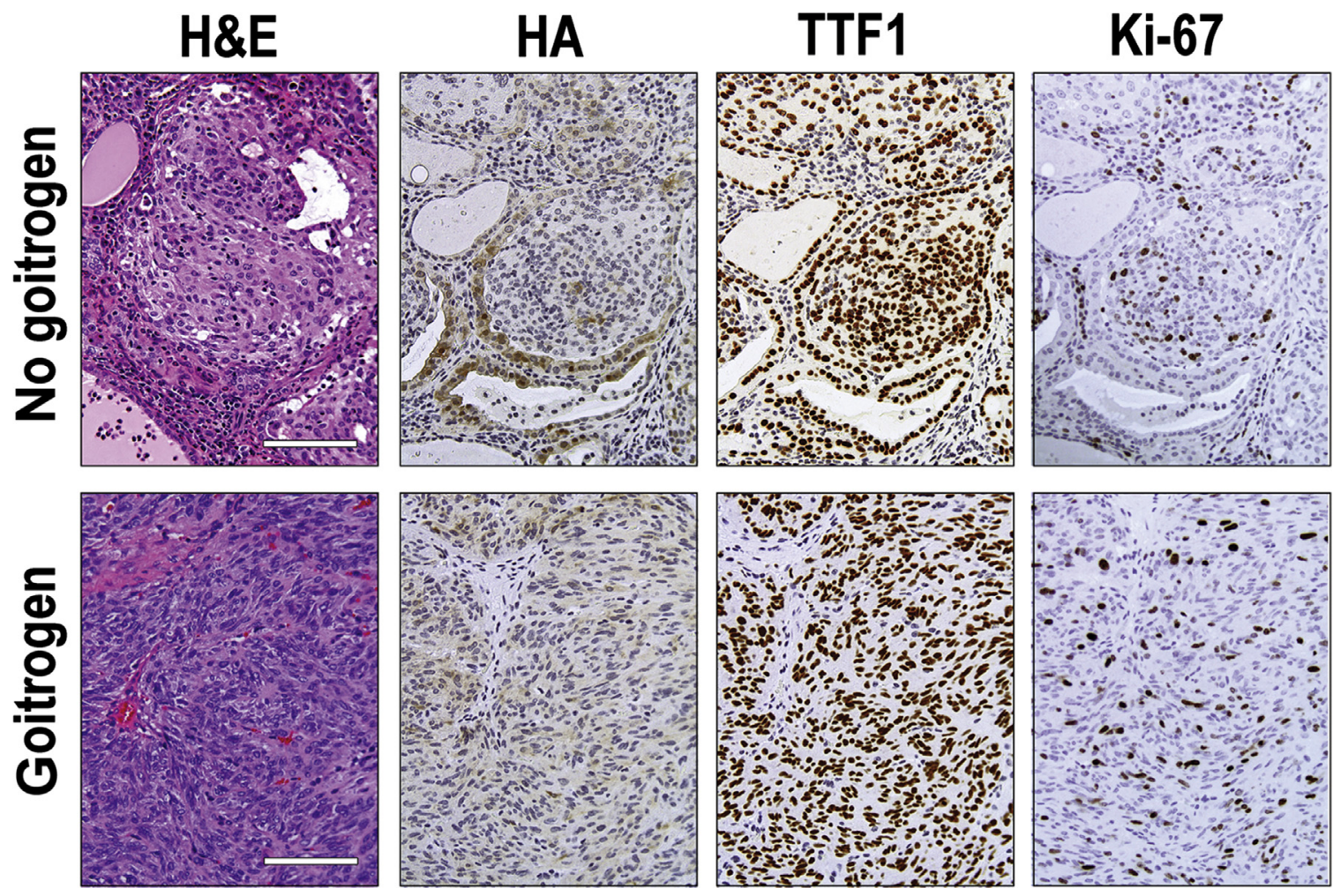

Figure 3 Immunohistochemical characterization of thyroid tumors developed in Tg-STRN-ALK mice with and without goitrogen treatment. The tumors demonstrate the expression of hemagglutinin (HA) that tags STRN-ALK, as well as positive staining for thyroid-specific factor TTF1, indicating thyroid follicular epithelial cell origin. High proliferation rate of tumor cells is indicated by Ki-67 immunostaining. Scale bars $=100 \mu \mathrm{m}$. Original magnification, $\times 200$. H\&E, hematoxylin and eosin.

reporter firefly luciferase-tandem dimmer Tomato, and HA-tagged STRN-ALK coding sequences was designed. Transcriptional activity of the bovine thyroglobulin promoter was confirmed by detection of the tandem dimmer Tomato red fluorescence and anti-HA immunoreactivity in normal thyroid HTori-3 cells transfected with the transgene encoding plasmid (Figure 1A). All generated Tg-STRN-ALK founder mice also showed thyroid-specific expression of the reporter and HA-tagged STRN-ALK proteins (Figure 1B). Founders were used to establish three strains of transgenic animals. All three strains expressed STRN-ALK, as confirmed by immunohistochemistry on formalin-fixed, paraffin-embedded sections (data not shown) and Western blot analysis of harvested thyroids (Figure 1, C and D). Thyroid endocrine function in $T g-S T R N-A L K$ mice was not impaired. Free thyroxine levels were within normal range, $3.34 \pm 0.39 \mathrm{ng} / \mathrm{dL}$. Strain 3, showing a higher level of STRN-ALK expression of three generated strains, was aged and subjected to further detailed analyses. In addition, to determine the contribution of thyroid-stimulating hormone (TSH) stimulation to the STRN-ALK-mediated thyroid tumor development, transgenic mice were treated with goitrogen.

$T g-S T R N-A L K$ mice developed poorly differentiated tumors by the age of 12 months (Table 1). In mice on a regular diet, tumors were observed in $22.2 \%$ (4/18) of cases, whereas in mice treated with goitrogen, the frequency of tumor development was $35.7 \%$ (5/14).

\section{Thyroid Tumors in Tg-STRN-ALK Mice Recapitulate Histologic Features of Human PDTC}

In the absence of goitrogen treatment, thyroid tumors in $T g$ $S T R N-A L K$ mice grew as solid nests of epithelial cells separated by thin layers of fibrovascular stroma (Figure 2A). Ki-67 labeling showed a highly proliferative index of $10 \% \pm 6 \%$. The growth of tumors was solid, with only occasional remnant microfollicles that lacked colloid. Tumor cells had a high nuclear/cytoplasm ratio. Significant infiltration by macrophages, lymphocytes, and eosinophils was noted.

In the presence of TSH stimulation, the tumors grew as confluent solid sheets of cells with a small amount of intervening fibrous stroma (Figure 2B). The cells showed high nuclear/cytoplasm ratio. Two populations of tumor cells were observed, round and spindle shaped (Figure 2C). Areas with round cells often had scattered small follicles, whereas areas with spindle cells had near complete loss of follicular organization. The tumors showed multiple mitotic figures and a high Ki-67 proliferation index of $29 \% \pm 9 \%$.

The microscopic features of tumors in Tg-STRN-ALK mice closely resembled human PDTC carrying $S T R N-A L K$, 


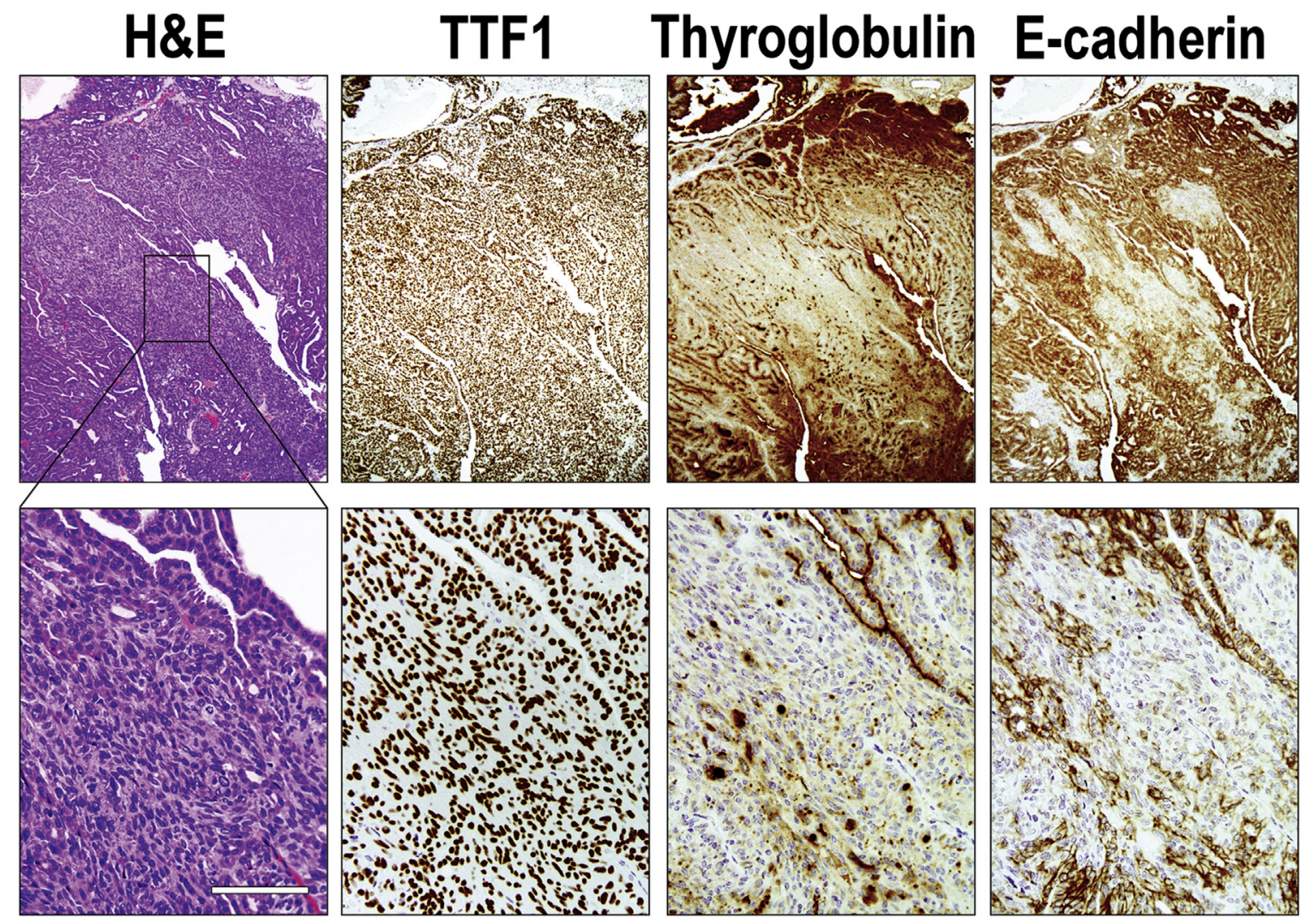

Figure 4 Immunohistochemical features of dedifferentiation in STRN-ALK-positive mouse tumors. Poorly differentiated tumor cells preserve expression of TTF1 but show decreased expression or complete loss of thyroglobulin and E-cadherin in focal areas of the tumor showing lack of follicular architecture on hematoxylin and eosin (H\&E) staining. Scale bar $=100 \mu \mathrm{m}$. Original magnifications: $\times 40$ (top row); $\times 200$ (bottom row).

which typically exhibits a solid pattern of growth, sheets of cells with either round- or spindle-shaped nuclei, and high proliferation activity (Figure 2C).

PDTCs in Tg-STRN-ALK Mice Show Preserved Expression of TTF1, Decreased Expression of Thyroglobulin, and Loss of E-Cadherin

Immunohistochemical staining was performed to assess the expression of STRN-ALK transgene as well as markers of thyroid cell differentiation in the mouse tumors. All tumors showed expression of HA-tagged STRN-ALK (Figure 3), although the intensity of immunoreactivity with anti-HA antibodies was lower in the tumor cells compared with the adjacent normal follicular cells. Thyroglobulin staining was weak and heterogeneous, with some tumor areas showing complete loss of immunoreactivity, particularly in tumors developed in mice treated with goitrogen. All tumors showed preserved expression of TTF1, indicating that they originated from thyroid follicular cells. However, in some areas of PDTC with spindle-cell morphology, the immunoreactivity to TTF1 was decreased (data not shown). In addition, in tumors from mice that received goitrogen treatment, the tumors showed a tendency to lose expression of E-cadherin (Figure 4).
Overall, the immunohistochemical pattern of thyroglobulin, TTF1, and E-cadherin expression in Tg-STRN-ALK tumors was consistent with gradual loss of differentiation, as seen in human PDTC.

\section{Discussion}

In this study, we established a mouse model of thyroidspecific expression of $S T R N-A L K$ fusion and demonstrated that $S T R N-A L K$ can drive the development of thyroid cancer. Furthermore, these transgenic animals were prone to develop tumors that closely recapitulate human PDTC, particularly after TSH stimulation.

Following the animal models of NPM1-ALK- and EML4-ALK-driven lymphomas and lung adenocarcinomas, respectively, ${ }^{44-47}$ we provide evidence for the oncogenic role of the STRN-ALK fusion in thyroid cancer. In these transgenic mice, the thyroid-specific expression of STRN$A L K$ alone triggered the development of poorly differentiated cancer. These findings are in accordance with our previous observation of $A L K$ gene fusions, mainly $S T R N$ $A L K$, in human thyroid tumors that were negative for other common driver mutations. ${ }^{42}$ In a more recent study of poorly differentiated and anaplastic thyroid cancers, two of three $A L K$ fusion-positive PDTCs had a coexisting ATM or 
TERT promoter mutation, whereas one tumor did not reveal any additional mutations. ${ }^{17}$

To date, $A L K$ gene chromosomal rearrangements have been reported in several types of thyroid cancer, but more frequently in PDTC. ${ }^{42,43,48-51}$ The $S T R N$ - $A L K$-driven tumors in mice observed in this study closely recapitulate the phenotype of $S T R N-A L K$-positive poorly differentiated thyroid carcinoma in humans. The tumors in $T g-S T R N-A L K$ mice showed a solid growth pattern with nests and sheets of highly proliferating tumor cells with a Ki-67 labeling index of approximately $10 \%$ to $30 \%$, the common features of PDTC in humans. ${ }^{14,52,53}$ Furthermore, the mouse and human tumors expressing STRN-ALK shared cytologic characteristics of tumor cells. Finally, thyroid tumors in $\mathrm{Tg}$ $S T R N-A L K$ mice recapitulated several immunohistochemical characteristics of PDTC in humans, demonstrating decreased levels of thyroglobulin and E-cadherin expression, while preserving the expression of TTF1. The decrease of E-cadherin expression has been shown to promote invasiveness in thyroid cancer driven by $B R A F^{\mathrm{V} 600 \mathrm{E}} \mathrm{mu}-$ tation, which likely occurs through a Snail-dependent mechanism. $^{54}$ Our findings suggest that STRN-ALK expression may have a similar effect on E-cadherin expression and tumor microenvironment, which should be dissected in future studies.

Mice with $S T R N-A L K$ expression treated with goitrogen were found to have more pronounced tumor growth with the formation of large, confluent sheets of tumor cells. A significant increase of $S T R N-A L K$ expression was not observed in mice receiving goitrogen treatment (data not shown) and, therefore, it is possible that such effect of increased TSH stimulation is attributable to its direct action on thyroid cells. In humans, higher TSH levels are associated with a higher risk of cancer development and possibly more advanced thyroid tumors. ${ }^{55-57}$ This may be caused by a stimulatory effect of TSH on cell proliferation and survival. ${ }^{58}$ The additive effect of TSH on thyroid tumor development and progression was previously observed in several strains of transgenic mice with thyroid-specific expression of Braf $^{\mathrm{V} 600 \mathrm{E}} 59$ These mice had a high TSH level as a result of impaired thyroid hormone production by the oncogene, and the aggressiveness of the developed tumors diminished when TSH signaling was blocked after inactivation of $T s h r$ or $G s \alpha$. In our mouse model of PDTC, the $S T R N-A L K$ transgene did not affect thyroid hormone synthesis, and we observed the development of high-grade poorly differentiated tumors in mice even without additional TSH stimulation. However, in the presence of goitrogen-induced additional TSH stimulation, Tg-STRN-ALK mice showed a more pronounced PDTC phenotype. Despite partial loss of thyroid differentiation, the tumors did not show complete loss of differentiation and transformation to ATC. Perhaps, the transformation to ATC requires additional genetic alterations, such as Trp53 inactivation.

The occurrence of $A L K$ fusions in human PDTC and confirmation of the carcinogenic role of these fusions in mice open a possibility for exploiting these alterations as a therapeutic target for treating patients with this aggressive type of thyroid cancer, particularly in light of the fact that these cancers are likely to be radioiodine resistant. In this respect, several US Food and Drug Administration-approved ALK tyrosine kinase inhibitors (crizotinib, ceritinib, and alectinib) are currently in use for the treatment of ALK-positive metastatic non-small-cell lung cancer, and excellent response to crizotinib treatment was reported in one case of ATC positive for $A L K$ fusion. ${ }^{38,60}$

In summary, we established a novel mouse strain with thyroid-specific expression of STRN-ALK fusion and showed that this oncogene can govern the development of murine PDTC that highly recapitulates PDTC in humans. This mouse model can be used for further studies of molecular mechanisms of thyroid tumor dedifferentiation and evaluation of known ALK tyrosine kinase inhibitors as well as the development of new targeted therapies.

\section{Supplemental Data}

Supplemental material for this article can be found at https://doi.org/10.1016/j.ajpath.2018.07.012.

\section{References}

1. Davies L, Welch HG: Increasing incidence of thyroid cancer in the United States, 1973-2002. JAMA 2006, 295:2164-2167

2. Kilfoy BA, Zheng T, Holford TR, Han X, Ward MH, Sjodin A, Zhang Y, Bai Y, Zhu C, Guo GL, Rothman N, Zhang Y: International patterns and trends in thyroid cancer incidence, 1973-2002. Cancer Causes Control 2009, 20:525-531

3. La Vecchia C, Malvezzi M, Bosetti C, Garavello W, Bertuccio P, Levi F, Negri E: Thyroid cancer mortality and incidence: a global overview. Int J Cancer 2015, 136:2187-2195

4. Siegel RL, Miller KD, Jemal A: Cancer statistics, 2017. CA Cancer J Clin 2017, 67:7-30

5. NCI. SEER Cancer Statistics Review, 1975-2013. Edited by Howlader N, Noone AM, Krapcho M, Miller D, Bishop K, Altekruse SF, Kosary CL, Yu M, Ruhl J, Tatalovich Z, Mariotto A, Lewis DR, Chen HS, Feuer EJ, Cronin KA. Bethesda, MD: National Cancer Institute, 2016

6. Smallridge RC, Copland JA: Anaplastic thyroid carcinoma: pathogenesis and emerging therapies. Clin Oncol (R Coll Radiol) 2010, 22 486-497

7. Ito $\mathrm{Y}$, Hirokawa M, Fukushima M, Inoue H, Yabuta T, Uruno T, Kihara M, Higashiyama T, Takamura Y, Miya A, Kobayashi K, Matsuzuka F, Miyauchi A: Prevalence and prognostic significance of poor differentiation and tall cell variant in papillary carcinoma in Japan. World J Surg 2008, 32:1535-1543. discussion 1544-1545

8. Asioli S, Erickson LA, Righi A, Jin L, Volante M, Jenkins S, Papotti M, Bussolati G, Lloyd RV: Poorly differentiated carcinoma of the thyroid: validation of the Turin proposal and analysis of IMP3 expression. Mod Pathol 2010, 23:1269-1278

9. Papotti M, Botto Micca F, Favero A, Palestini N, Bussolati G: Poorly differentiated thyroid carcinomas with primordial cell component: a group of aggressive lesions sharing insular, trabecular, and solid patterns. Am J Surg Pathol 1993, 17:291-301

10. Pilotti S, Collini P, Manzari A, Marubini E, Rilke F: Poorly differentiated forms of papillary thyroid carcinoma: distinctive entities or morphological patterns? Semin Diagn Pathol 1995, 12:249-255 
11. Pietribiasi F, Sapino A, Papotti M, Bussolati G: Cytologic features of poorly differentiated "insular" carcinoma of the thyroid, as revealed by fine-needle aspiration biopsy. Am J Clin Pathol 1990, 94:687-692

12. Kazaure HS, Roman SA, Sosa JA: Insular thyroid cancer: a population-level analysis of patient characteristics and predictors of survival. Cancer 2012, 118:3260-3267

13. Bongiovanni M, Sadow PM, Faquin WC: Poorly differentiated thyroid carcinoma: a cytologic-histologic review. Adv Anat Pathol 2009. $16: 283-289$

14. Volante M, Collini P, Nikiforov YE, Sakamoto A, Kakudo K, Katoh R, Lloyd RV, Livolsi VA, Papotti M, Sobrinho-Simoes M, Bussolati G, Rosai J: Poorly differentiated thyroid carcinoma: the Turin proposal for the use of uniform diagnostic criteria and an algorithmic diagnostic approach. Am J Surg Pathol 2007, 31: $1256-1264$

15. Nonaka D, Tang Y, Chiriboga L, Rivera M, Ghossein R: Diagnostic utility of thyroid transcription factors Pax 8 and TTF-2 (FoxE1) in thyroid epithelial neoplasms. Mod Pathol 2008, 21:192-200

16. Bejarano PA, Nikiforov YE, Swenson ES, Biddinger PW: Thyroid transcription factor-1, thyroglobulin, cytokeratin 7, and cytokeratin 20 in thyroid neoplasms. Appl Immunohistochem Mol Morphol 2000, 8: 189-194

17. Landa I, Ibrahimpasic T, Boucai L, Sinha R, Knauf JA, Shah RH, Dogan S, Ricarte-Filho JC, Krishnamoorthy GP, Xu B, Schultz N, Berger MF, Sander C, Taylor BS, Ghossein R, Ganly I, Fagin JA: Genomic and transcriptomic hallmarks of poorly differentiated and anaplastic thyroid cancers. J Clin Invest 2016, 126:1052-1066

18. Basolo F, Pisaturo F, Pollina LE, Fontanini G, Elisei R, Molinaro E, Iacconi P, Miccoli P, Pacini F: N-ras mutation in poorly differentiated thyroid carcinomas: correlation with bone metastases and inverse correlation to thyroglobulin expression. Thyroid 2000, 10:19-23

19. Rocha AS, Soares P, Fonseca E, Cameselle-Teijeiro J, Oliveira MC, Sobrinho-Simoes M: E-cadherin loss rather than beta-catenin alterations is a common feature of poorly differentiated thyroid carcinomas. Histopathology 2003, 42:580-587

20. Cancer Genome Atlas Research Network: Integrated genomic characterization of papillary thyroid carcinoma. Cell 2014, 159:676-690

21. Yoo SK, Lee S, Kim SJ, Jee HG, Kim BA, Cho H, Song YS, Cho SW, Won JK, Shin JY, Park do J, Kim JI, Lee KE, Park YJ, Seo JS: Comprehensive analysis of the transcriptional and mutational landscape of follicular and papillary thyroid cancers. PLoS Genet 2016, 12:e1006239

22. Xu B, Ghossein R: Genomic landscape of poorly differentiated and anaplastic thyroid carcinoma. Endocr Pathol 2016, 27:205-212

23. Penna GC, Vaisman F, Vaisman M, Sobrinho-Simoes M, Soares P: Molecular markers involved in tumorigenesis of thyroid carcinoma: focus on aggressive histotypes. Cytogenet Genome Res 2016, 150: 194-207

24. Nikiforov YE: Genetic alterations involved in the transition from well-differentiated to poorly differentiated and anaplastic thyroid carcinomas. Endocr Pathol 2004, 15:319-327

25. Xing M: Molecular pathogenesis and mechanisms of thyroid cancer. Nat Rev 2013, 13:184-199

26. Nikiforov YE, Nikiforova MN: Molecular genetics and diagnosis of thyroid cancer. Nat Rev Endocrinol 2011, 7:569-580

27. McFadden DG, Vernon A, Santiago PM, Martinez-McFaline R, Bhutkar A, Crowley DM, McMahon M, Sadow PM, Jacks T: p53 Constrains progression to anaplastic thyroid carcinoma in a Brafmutant mouse model of papillary thyroid cancer. Proc Natl Acad Sci U S A 2014, 111:E1600-E1609

28. Charles RP, Silva J, Iezza G, Phillips WA, McMahon M: Activating BRAF and PIK3CA mutations cooperate to promote anaplastic thyroid carcinogenesis. Mol Cancer Res 2014, 12:979-986

29. Zhu X, Zhao L, Park JW, Willingham MC, Cheng SY: Synergistic signaling of KRAS and thyroid hormone receptor beta mutants promotes undifferentiated thyroid cancer through MYC up-regulation. Neoplasia 2014, 16:757-769
30. Antico Arciuch VG, Russo MA, Dima M, Kang KS, Dasrath F, Liao XH, Refetoff S, Montagna C, Di Cristofano A: Thyrocytespecific inactivation of p53 and Pten results in anaplastic thyroid carcinomas faithfully recapitulating human tumors. Oncotarget 2011, 2:1109-1126

31. La Perle KM, Jhiang SM, Capen CC: Loss of p53 promotes anaplasia and local invasion in ret/PTC1-induced thyroid carcinomas. Am J Pathol 2000, 157:671-677

32. Knauf JA, Ma X, Smith EP, Zhang L, Mitsutake N, Liao XH, Refetoff S, Nikiforov YE, Fagin JA: Targeted expression of BRAFV600E in thyroid cells of transgenic mice results in papillary thyroid cancers that undergo dedifferentiation. Cancer Res 2005, 65: $4238-4245$

33. Knauf JA, Sartor MA, Medvedovic M, Lundsmith E, Ryder M, Salzano M, Nikiforov YE, Giordano TJ, Ghossein RA, Fagin JA: Progression of BRAF-induced thyroid cancer is associated with epithelial-mesenchymal transition requiring concomitant MAP kinase and TGFbeta signaling. Oncogene 2011, 30:3153-3162

34. Chakravarty D, Santos E, Ryder M, Knauf JA, Liao XH, West BL, Bollag G, Kolesnick R, Thin TH, Rosen N, Zanzonico P, Larson SM, Refetoff S, Ghossein R, Fagin JA: Small-molecule MAPK inhibitors restore radioiodine incorporation in mouse thyroid cancers with conditional BRAF activation. J Clin Invest 2011, 121:4700-4711

35. Vitagliano D, Portella G, Troncone G, Francione A, Rossi C, Bruno A, Giorgini A, Coluzzi S, Nappi TC, Rothstein JL, Pasquinelli R, Chiappetta G, Terracciano D, Macchia V, Melillo RM, Fusco A, Santoro M: Thyroid targeting of the N-ras(Gln61Lys) oncogene in transgenic mice results in follicular tumors that progress to poorly differentiated carcinomas. Oncogene 2006, 25:5467-5474

36. Morris SW, Kirstein MN, Valentine MB, Dittmer KG, Shapiro DN, Saltman DL, Look AT: Fusion of a kinase gene, ALK, to a nucleolar protein gene, NPM, in non-Hodgkin's lymphoma. Science 1994, 263: $1281-1284$

37. Lamant L, Dastugue N, Pulford K, Delsol G, Mariame B: A new fusion gene TPM3-ALK in anaplastic large cell lymphoma created by a (1;2)(q25;p23) translocation. Blood 1999, 93:3088-3095

38. Holla VR, Elamin YY, Bailey AM, Johnson AM, Litzenburger BC, Khotskaya YB, Sanchez NS, Zeng J, Shufean MA, Shaw KR, Mendelsohn J, Mills GB, Meric-Bernstam F, Simon GR: ALK: a tyrosine kinase target for cancer therapy. Cold Spring Harb Mol Case Stud 2017, 3:a001115

39. Barreca A, Lasorsa E, Riera L, Machiorlatti R, Piva R, Ponzoni M, Kwee I, Bertoni F, Piccaluga PP, Pileri SA, Inghirami G; European TCell Lymphoma Study Group: Anaplastic lymphoma kinase in human cancer. J Mol Endocrinol 2011, 47:R11-R23

40. Lin E, Li L, Guan Y, Soriano R, Rivers CS, Mohan S, Pandita A, Tang J, Modrusan Z: Exon array profiling detects EML4-ALK fusion in breast, colorectal, and non-small cell lung cancers. Mol Cancer Res 2009, 7:1466-1476

41. Soda M, Choi YL, Enomoto M, Takada S, Yamashita Y, Ishikawa S, Fujiwara S, Watanabe H, Kurashina K, Hatanaka H, Bando M, Ohno S, Ishikawa Y, Aburatani H, Niki T, Sohara Y, Sugiyama Y, Mano H: Identification of the transforming EML4-ALK fusion gene in non-small-cell lung cancer. Nature 2007, 448:561-566

42. Kelly LM, Barila G, Liu P, Evdokimova VN, Trivedi S, Panebianco F, Gandhi M, Carty SE, Hodak SP, Luo J, Dacic S, Yu YP, Nikiforova MN, Ferris RL, Altschuler DL, Nikiforov YE: Identification of the transforming STRN-ALK fusion as a potential therapeutic target in the aggressive forms of thyroid cancer. Proc Natl Acad Sci U S A 2014, 111:4233-4238

43. Chou A, Fraser S, Toon CW, Clarkson A, Sioson L, Farzin M, Cussigh C, Aniss A, O'Neill C, Watson N, Clifton-Bligh RJ, Learoyd DL, Robinson BG, Selinger CI, Delbridge LW, Sidhu SB, O'Toole SA, Sywak M, Gill AJ: A detailed clinicopathologic study of ALK-translocated papillary thyroid carcinoma. Am J Surg Pathol 2015, 39:652-659 
44. Soda M, Takada S, Takeuchi K, Choi YL, Enomoto M, Ueno T, Haruta H, Hamada T, Yamashita Y, Ishikawa Y, Sugiyama Y, Mano H: A mouse model for EML4-ALK-positive lung cancer. Proc Natl Acad Sci U S A 2008, 105:19893-19897

45. Chiarle R, Gong JZ, Guasparri I, Pesci A, Cai J, Liu J, Simmons WJ, Dhall G, Howes J, Piva R, Inghirami G: NPM-ALK transgenic mice spontaneously develop T-cell lymphomas and plasma cell tumors. Blood 2003, 101:1919-1927

46. Turner SD, Alexander DR: What have we learnt from mouse models of NPM-ALK-induced lymphomagenesis? Leukemia 2005, 19: $1128-1134$

47. Maddalo D, Manchado E, Concepcion CP, Bonetti C, Vidigal JA, Han YC, Ogrodowski P, Crippa A, Rekhtman N, de Stanchina E, Lowe SW, Ventura A: In vivo engineering of oncogenic chromosomal rearrangements with the CRISPR/Cas9 system. Nature 2014, 516:423-427

48. Hamatani K, Mukai M, Takahashi K, Hayashi Y, Nakachi K, Kusunoki Y: Rearranged anaplastic lymphoma kinase (ALK) gene in adult-onset papillary thyroid cancer amongst atomic bomb survivors. Thyroid 2012, 22:1153-1159

49. Efanov AA, Brenner AV, Bogdanova TI, Kelly LM, Liu P, Little MP, Wald AI, Hatch M, Zurnadzy LY, Nikiforova MN, Drozdovitch V, Mabuchi K, Tronko MD, Chanock SJ, Nikiforov YE: Investigation of the relationship between radiation dose and gene mutations and fusions in post-Chernobyl thyroid cancer. J Natl Cancer Inst 2018, 110:371-378

50. Ji JH, Oh YL, Hong M, Yun JW, Lee HW, Kim D, Ji Y, Kim DH, Park WY, Shin HT, Kim KM, Ahn MJ, Park K, Sun JM: Identification of driving ALK fusion genes and genomic landscape of medullary thyroid cancer. PLoS Genet 2015, 11:e1005467

51. Perot G, Soubeyran I, Ribeiro A, Bonhomme B, Savagner F, BoutetBouzamondo N, Hostein I, Bonichon F, Godbert Y, Chibon F: Identification of a recurrent STRN/ALK fusion in thyroid carcinomas. PLoS One 2014, 9:e87170

52. Tallini G, Garcia-Rostan G, Herrero A, Zelterman D, Viale G, Bosari S, Carcangiu ML: Downregulation of p27KIP1 and Ki67/Mib1 labeling index support the classification of thyroid carcinoma into prognostically relevant categories. Am J Surg Pathol 1999, 23:678-685
53. Lloyd RV, Osamura RY, Klöppel G, Rosai J: World Health Organization Classification of Tumours of Endocrine Organs. Lyon, France, IARC Press, 2017

54. Baquero P, Sanchez-Hernandez I, Jimenez-Mora E, Orgaz JL, Jimenez B, Chiloeches A: (V600E)BRAF promotes invasiveness of thyroid cancer cells by decreasing E-cadherin expression through a Snail-dependent mechanism. Cancer Lett 2013, 335:232-241

55. Haymart MR, Repplinger DJ, Leverson GE, Elson DF, Sippel RS, Jaume JC, Chen H: Higher serum thyroid stimulating hormone level in thyroid nodule patients is associated with greater risks of differentiated thyroid cancer and advanced tumor stage. J Clin Endocrinol Metab 2008, 93:809-814

56. Kim SS, Lee BJ, Lee JC, Song SH, Kim BH, Son SM, Kim IJ, Kim YK, Kang YH: Preoperative serum thyroid stimulating hormone levels in well-differentiated thyroid carcinoma is a predictive factor for lateral lymph node metastasis as well as extrathyroidal extension in Korean patients: a single-center experience. Endocrine 2011, 39: 259-265

57. McLeod DS, Cooper DS, Ladenson PW, Ain KB, Brierley JD, Fein HG, Haugen BR, Jonklaas J, Magner J, Ross DS, Skarulis MC, Steward DL, Maxon HR, Sherman SI; The National Thyroid Cancer Treatment Cooperative Study Group: Prognosis of differentiated thyroid cancer in relation to serum thyrotropin and thyroglobulin antibody status at time of diagnosis. Thyroid 2014, 24:35-42

58. Kimura T, Van Keymeulen A, Golstein J, Fusco A, Dumont JE, Roger PP: Regulation of thyroid cell proliferation by TSH and other factors: a critical evaluation of in vitro models. Endocr Rev 2001, 22: $631-656$

59. Franco AT, Malaguarnera R, Refetoff S, Liao XH, Lundsmith E, Kimura S, Pritchard C, Marais R, Davies TF, Weinstein LS, Chen M, Rosen N, Ghossein R, Knauf JA, Fagin JA: Thyrotrophin receptor signaling dependence of Braf-induced thyroid tumor initiation in mice. Proc Natl Acad Sci U S A 2011, 108:1615-1620

60. Godbert Y, Henriques de Figueiredo B, Bonichon F, Chibon F, Hostein I, Perot G, Dupin C, Daubech A, Belleannee G, Gros A, Italiano A, Soubeyran I: Remarkable response to crizotinib in woman with anaplastic lymphoma kinase-rearranged anaplastic thyroid carcinoma. J Clin Oncol 2015, 33:e84-e87 